ORNL/ LTR-2017/107

\title{
Results of a Pilot-Scale Disinfection Test using Peracetic Acid (PAA) at the Oak Ridge National Laboratory (ORNL) Sewage Treatment Plant (STP)
}

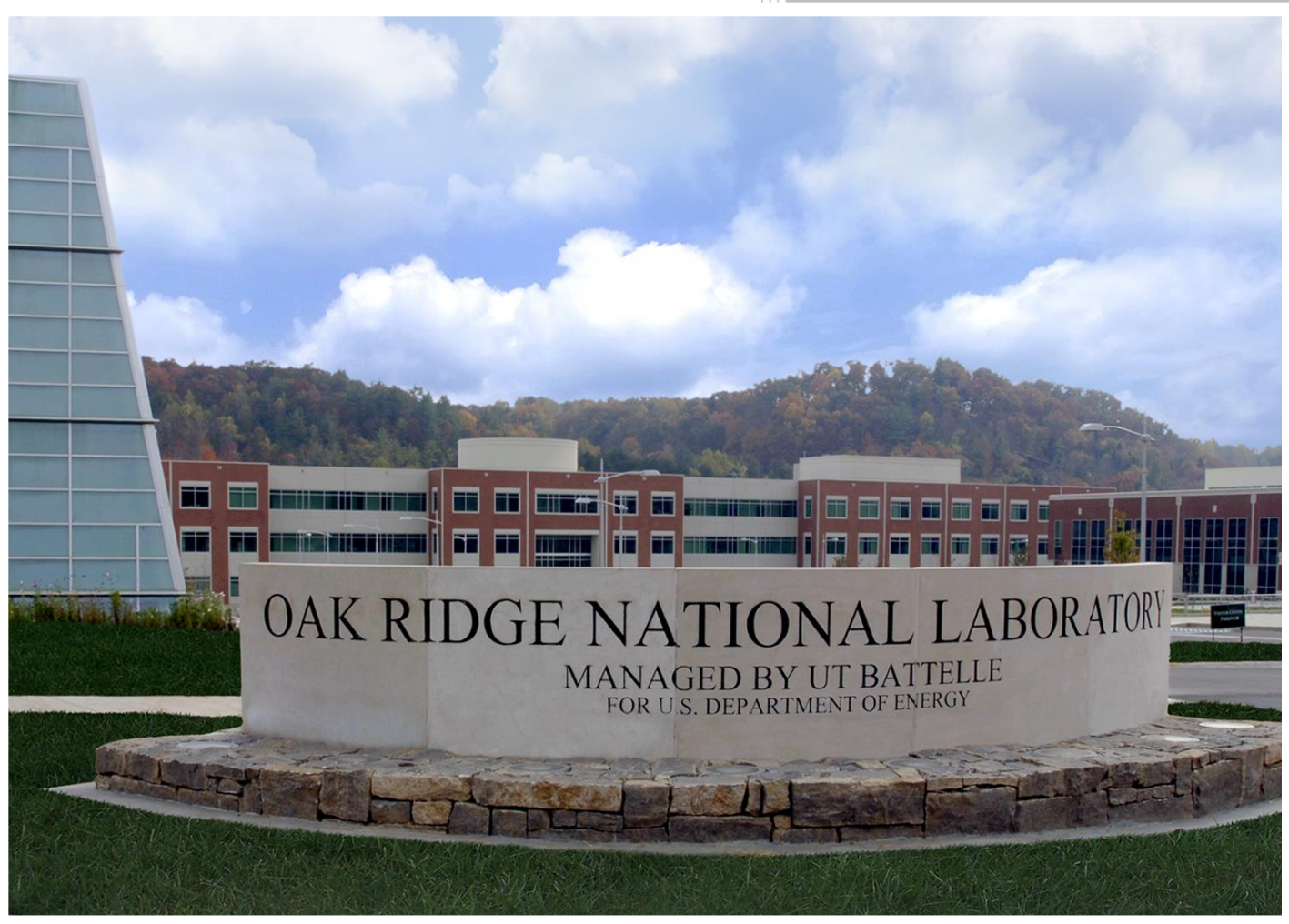

Approved for public release. Distribution is unlimited.
Paul Taylor

March 2017 


\section{DOCUMENT AVAILABILITY}

Reports produced after January 1, 1996, are generally available free via US Department of Energy (DOE) SciTech Connect.

Website http://www.osti.gov/scitech/

Reports produced before January 1, 1996, may be purchased by members of the public from the following source:

National Technical Information Service

5285 Port Royal Road

Springfield, VA 22161

Telephone 703-605-6000 (1-800-553-6847)

TDD 703-487-4639

Fax 703-605-6900

E-mail info@ntis.gov

Website http://www.ntis.gov/help/ordermethods.aspx

Reports are available to DOE employees, DOE contractors, Energy Technology Data Exchange representatives, and International Nuclear Information System representatives from the following source:

Office of Scientific and Technical Information

PO Box 62

Oak Ridge, TN 37831

Telephone 865-576-8401

Fax 865-576-5728

E-mail reports@osti.gov

Website http://www.osti.gov/contact.html

This report was prepared as an account of work sponsored by an agency of the United States Government. Neither the United States Government nor any agency thereof, nor any of their employees, makes any warranty, express or implied, or assumes any legal liability or responsibility for the accuracy, completeness, or usefulness of any information, apparatus, product, or process disclosed, or represents that its use would not infringe privately owned rights. Reference herein to any specific commercial product, process, or service by trade name, trademark, manufacturer, or otherwise, does not necessarily constitute or imply its endorsement, recommendation, or favoring by the United States Government or any agency thereof. The views and opinions of authors expressed herein do not necessarily state or reflect those of the United States Government or any agency thereof. 
Nuclear Security and isotope Technology Division

\title{
Results of a Pilot-Scale Disinfection Test using Peracetic Acid (PAA) at the Oak Ridge National Laboratory (ORNL) Sewage Treatment Plant (STP)
}

\author{
Paul Taylor
}

Date Published:

March 2017

\author{
Prepared by \\ OAK RIDGE NATIONAL LABORATORY \\ Oak Ridge, Tennessee 37831-6283 \\ managed by \\ UT-BATTELLE, LLC \\ for the \\ US DEPARTMENT OF ENERGY \\ under contract DE-AC05-00OR22725
}





\section{INTRODUCTION}

\section{Background}

Disinfection at ORNL's STP was originally carried out through the addition of chlorine, which requires dechlorination of the treated waste prior to discharge to the receiving stream. Because of occasional failures with the dechlorination system, toxic concentrations of chlorine were occasionally released to the creek. To address these issues, and concerns over the formation of toxic chlorinated byproducts (e.g., trihalomethanes), the decision was made to switch to ozone disinfection, which has been in place for about 20 years.

Ozone disinfection is an energy intensive method that is also maintenance intensive to keep the systems operating properly and presents safety concerns from worker exposure. For these reasons, the use of peracetic acid (PAA) is being evaluated as a replacement for the ozone treatment.

\section{Purpose}

The purpose of this report is to present the results of a small pilot-scale test using PAA to disinfect a side stream of the effluent from the ORNL STP. These results provide the basis for requesting approval for full-scale use of PAA at the ORNL STP.

\section{PAA Strategy}

Commercial PAA solutions are a mixture of PAA, acetic acid, hydrogen peroxide, and water. When PAA decomposes in water, hydrogen peroxyl $\left(\mathrm{HO}_{2}\right)$ and hydroxyl $(\mathrm{OH})$ radicals are formed, which are very strong oxidizers. These free radicals are very effective in killing pathogens. The decomposition of the PAA to meet the oxidant demand of a wastewater occurs rapidly, which results in the rapid dissipation of PAA residuals if dosage rates are kept at equilibrium with oxidant demand.

The existing contact chamber for the ORNL STP was designed to provide disinfection using chlorine, but was converted for ozone use. The design of the chamber provides sufficient volume for an average of 25 minutes retention time at the treatment facility's design flow rate. This is a sufficient retention time to allow for disinfection and decay of PAA residuals. Should additional PAA removal be required, it can be neutralized by adding sodium metabisulfite; however, due to the low dosages required for disinfection and the rapid decay this should not be necessary. The pilot-scale study evaluated the required dosage rates for disinfection and measured the residual PAA concentration in the effluent.

Based on the results, design plans and supporting documentation will be finalized and submitted to TDEC for approval to install a permanent PAA system to replace the ozone generators. However, the existing ozone system will be kept as a backup option.

\section{Water Quality Standards}

TDEC has not at this time developed a maximum contaminant level for PAA. The by-products of PAA decomposition are also non-listed compounds. Because of this, the mandated limitation for feeding PAA for disinfection of the wastewater effluent is to maintain de minimis degradation to the quality of the receiving stream. 
The receiving stream for the STP is White Oak Creek (WOC), which has a 7Q10 of 950,000 gallons per day (gpd) at the point of discharge. At a design discharge rate of 300,000 gpd, the dilution factor for the STP discharge into the receiving stream's designated drought flow is $\sim 3$. This presents a moderate amount of dilution but not enough to forgo relatively rigorous effluent controls for disinfectant residuals. Because of the use of ozone, the permit currently does not require the monitoring of disinfectant residuals. Therefore, a safe concentration for PAA residuals needs to be developed for future monitoring purposes.

The use of PAA has been explored for other STP systems in Tennessee. In Lexington the most sensitive aquatic species was green algae, which had an effective concentration $\left(\mathrm{EC}_{50}\right)$ value of $0.18 \mathrm{mg} / \mathrm{L}$ and the no observed effect concentration (NOEC) value was found to be $0.12 \mathrm{mg} / \mathrm{L}$. In Tullahoma the $25 \%$ inhibition concentration $\left(\mathrm{IC}_{25}\right)$ values for Ceriodaphania dubia and Pimephales promelas were 0.38 and $0.75 \mathrm{mg} / \mathrm{L}$, respectively. Currently TDEC has identified $\mathrm{IC}_{25}$ values for Ceriodaphania dubia and Pimephales promelas as acceptable indicators of water quality for PAA residuals.

Other potential indicators of stream quality degradation would be impacts to the benthic communities near the outfall. However, in consideration of the design of the contact chamber and the dilution factor of the receiving stream it is unlikely that the appropriate dosage of PAA at the ORNL STP will have an effect on the water quality of the receiving stream.

\section{MATERIALS AND METHODS}

The pilot-scale study used a side stream of effluent from the ORNL STP, collected after filtration but prior to ozone addition. The side stream $(\sim 1 \mathrm{~L} / \mathrm{min})$ was pumped to a small, baffled contact chamber $(\sim 25 \mathrm{~L})$, and a diluted stock solution of PAA was added to the side stream just before it entered the contact chamber, giving a retention time of about $25 \mathrm{~min}$ for the PAA to deactivate the bacteria (same as full-scale contact chamber design). A flow diagram of the pilot-scale system is shown in Figure 1. Effluent from the pilot-scale system was discharged into the STP contact chamber. The pump for the STP effluent was a gear pump with an electronic speed control. The pump for the diluted PAA solution was a peristaltic pump with manual speed control, using 1/16" I.D. silicon rubber tubing. A photo of the system is shown in Figure 2.

A sample of Peragreen 22WW PAA solution was obtained from Enviro Tech Chemical Services, Inc. (Modesto, CA), which contains 21-23\% PAA, 4.2-5.2\% hydrogen peroxide $\left(\mathrm{H}_{2} \mathrm{O}_{2}\right)$ and 40-50\% acetic acid in water. A second PAA solution, VigorOx WWT II, was obtained from PeroxyChem, LLC (Philadelphia, PA), which contains $15 \%$ PAA, 23\% $\mathrm{H}_{2} \mathrm{O}_{2}$ and $16 \%$ acetic acid in water. Each PAA solution was used during the pilot-scale testing. Diluted stock solutions ( 100:1) were pumped into the STP effluent just before it entered the pilot-scale contact chamber. The concentration of PAA entering the contact chamber was adjusted to determine the range of concentrations that provide good disinfection with low residual PAA concentration in the effluent. As the PAA reacts, either with organics/bacteria in the contact chamber or spontaneously in the stock solution, $\mathrm{H}_{2} \mathrm{O}_{2}$ is formed, which can also degrade, but usually more slowly than the PAA. Because of these reactions, the ratio of PAA to $\mathrm{H}_{2} \mathrm{O}_{2}$ in samples from the pilot-scale system can vary considerably. 


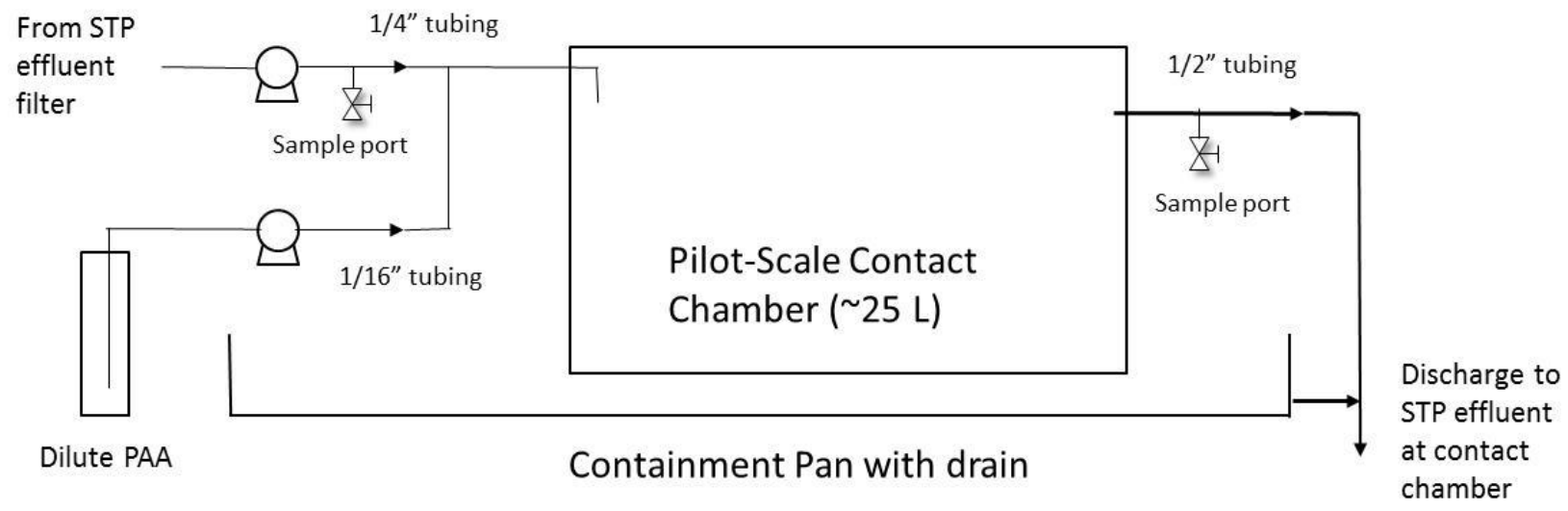

Fig. 1. Flow diagram of pilot-scale system
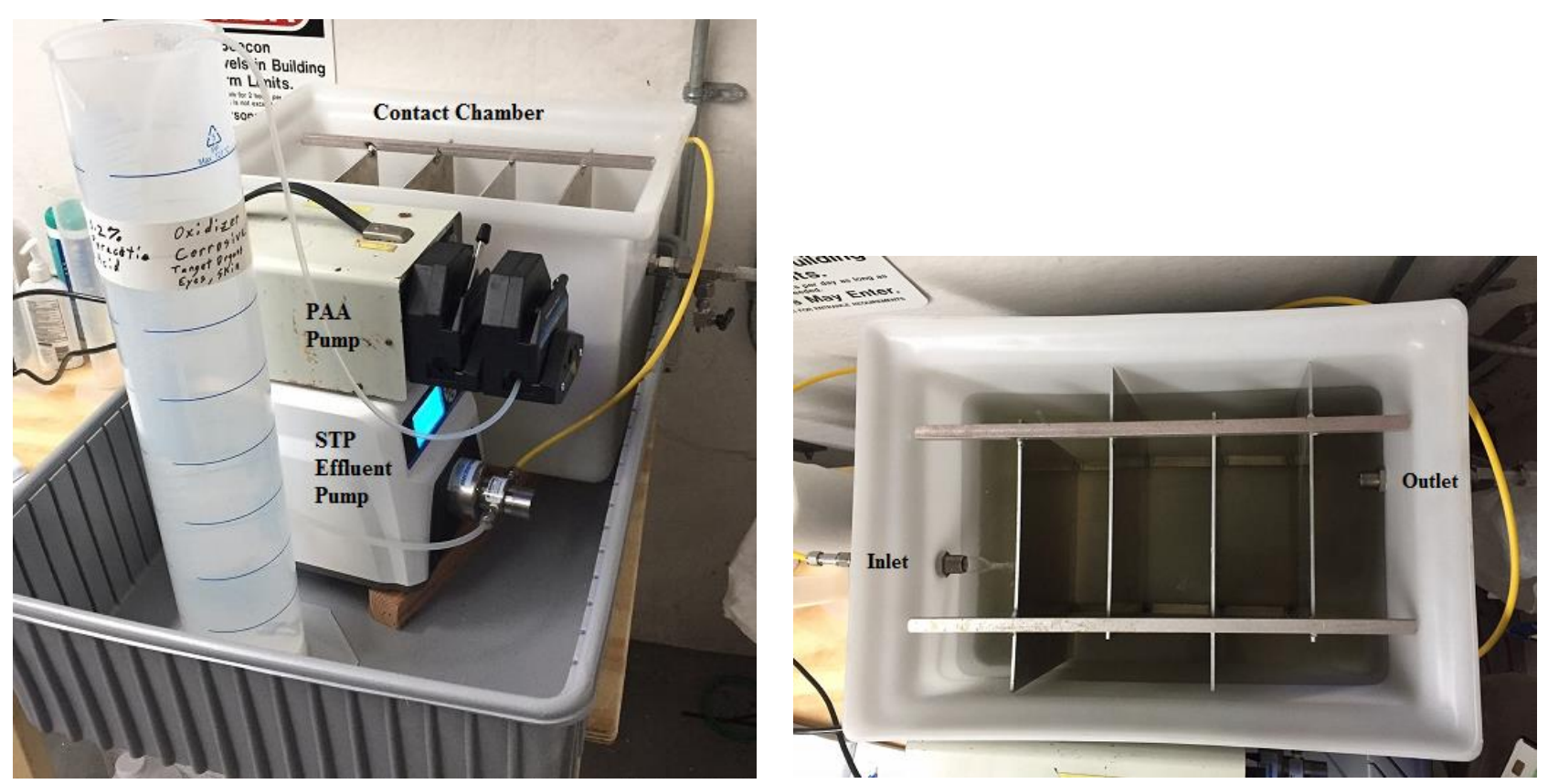

Fig. 2. Pilot-scale system (left) and top view of contact chamber (right)

The PAA and $\mathrm{H}_{2} \mathrm{O}_{2}$ concentrations were measured using a Colorimeter and DPD (N,N Diethyl-1,4 Phenylenediamine Sulfate) reagent powder, both from Hach Company (Loveland, CO). The analyses followed the procedure in Application Note - Determination of Peracetic Acid and Hydrogen Peroxide in Water from Hach. For PAA analysis, each sample is analyzed using the standard method for total chlorine, and then this result is multiplied by 1.07 to calculate the concentration of PAA. $\mathrm{H}_{2} \mathrm{O}_{2}$ does not react directly with the DPD reagent; however, adding 3 drops each of $20 \%$ potassium iodide solution and $4 \%$ ammonium molybdate solution and letting the solution react for 6 minutes converts the hydrogen peroxide to an equal molar concentration of iodine, which does react with DPD. The measured concentration is the combined amount of PAA and hydrogen peroxide. Subtracting the measured PAA 
concentration from the combined value and multiplying by 0.478 gives the $\mathrm{H}_{2} \mathrm{O}_{2}$ concentration. Because of the large dilution of the pilot-scale effluent into the STP discharge (at least 300:1), any PAA and $\mathrm{H}_{2} \mathrm{O}_{2}$ left in the pilot-scale effluent will immediately be diluted to vanishingly low concentrations before entering White Oak Creek.

The E. coli concentration in the effluent from the pilot-scale system was measured using EPA Method 1603: Escherichia coli (E. coli) in Water by Membrane Filtration Using Modified Membrane-

Thermotolerant Escherichia coli Agar (modified mTEC). Method 1603 provides a direct count of E. coli in ambient water or wastewater based on the development of colonies that grow on the surface of a membrane filter. A sample is filtered through the membrane, which retains the bacteria. After filtration, the membrane is placed on a selective and differential medium (modified mTEC agar) incubated at $35^{\circ} \mathrm{C}$ $\pm 0.5^{\circ} \mathrm{C}$ for $2 \pm 0.5$ hours to resuscitate injured or stressed bacteria, and then incubated at $44.5^{\circ} \mathrm{C} \pm 0.2^{\circ} \mathrm{C}$ for $22 \pm 2$ hours. The target colonies on modified mTEC agar are red or magenta in color after the incubation period.

Carbonaceous biological oxygen demand (cBOD) (EPA Method 5210B in Standard Methods for the Examination of Water and Wastewater) was periodically measured in the effluent of the pilot-scale system to determine the impact of the acetic acid in the PAA solution on the cBOD of the effluent.

A 48-hour static acute toxicity test was conducted on an effluent sample using Ceriodaphnia dubia (a water flea), as described in EPA Test Method 2002.0 (P. A. Lewis et al., Methods for Measuring the Acute Toxicity of Effluent and Receiving Water to Freshwater and Marine Organisms, EPA/821-R-02012, October 2002, 5th Ed). Testing of PAA at the Tullahoma sewage treatment plant (see p. 2) showed that Ceriodaphania was more sensitive to PAA than Pimephales promelas (fathead minnows). Toxicity tests, using Ceriodaphania and fathead minnows, are routinely conducted at the ORNL STP, and Ceriodaphania is usually the more sensitive species when toxicity is detected, which happens rarely.

\section{RESULTS AND DISCUSSION}

The pilot-scale test was started on 12/19/2016, using the Peragreen 22WW PAA solution. The first batch of diluted stock solution contained $2760 \mathrm{mg} / \mathrm{L} \mathrm{PAA}$ and $411 \mathrm{mg} / \mathrm{L} \mathrm{H}_{2} \mathrm{O}_{2}$, as measured by the colorimeter. The flow rate of the STP effluent into the contact chamber was measured by bucket gauge (placing a beaker into the flow for a timed interval) and the flow rate of the PAA solution is determined by the change in volume of the stock solution in the feed tank (graduated cylinder) over long time spans, typically $24 \mathrm{hr}$. The concentrations of PAA and $\mathrm{H}_{2} \mathrm{O}_{2}$ were measured each work day for the inlet and outlet streams of the pilot-scale contact chamber. Samples for E. coli and cBOD were taken to the ORNL Radioactive Materials Analysis Laboratory, which also analyzes samples from the ORNL STP.

Table 1 shows the concentrations of PAA and $\mathrm{H}_{2} \mathrm{O}_{2}$ in the influent and effluent of the pilot-scale contact chamber, and the $\mathrm{pH}$, temperature and E. coli concentration of the effluent. The Peragreen 22WW PAA solution was used until 1/11/17 and then the VigorOx WWT II solution was used until the end of the testing. Figure 3 shows a graph of the PAA concentrations and the concentration of E. coli in the effluent. The National Pollutant Discharge Elimination System (NPDES) permit for the ORNL STP limits E. coli to less than 126 colony forming units $(\mathrm{CFU}) / 100 \mathrm{~mL}$ for a monthly average. The $E$. coli concentration for the pilot-scale system was generally $<10 \mathrm{CFU} / 100 \mathrm{~mL}$. The three samples that are shown as 100 $\mathrm{CFU} / 100 \mathrm{~mL}$ on the graph were actually reported as TNTC (too numerous to count). For all of the samples, $100 \mathrm{~mL}$ of effluent was filtered during the determination, so any concentration above about 100 would be reported as TNTC. The $E$. coli concentration in the influent to the pilot-scale system, prior to PAA addition, was measured once per week. Volumes of 1.0 and $10 \mathrm{~mL}$ were filtered for these measurements, so the quantification limit is much higher. The concentration in the influent averaged 
$3221 \mathrm{CFU} / 100 \mathrm{~mL}$, with a high of 17,200 CFU/100 mL. E. coli concentrations are measured once a week for the STP effluent. During the time period that the pilot-scale system was operating, the NPDES concentrations for the ORNL STP averaged $39 \mathrm{CFU} / 100 \mathrm{~mL}$, with a maximum of $210 \mathrm{CFU} / 100 \mathrm{~mL}$. The maximum occurred on 1/31/17, when the effluent entering the contact chamber contained 17,200 CFU/100 mL. The pilot-scale effluent contained $<1 \mathrm{CFU} / 100 \mathrm{~mL}$ on this day.

Table 1. PAA and $\mathrm{H}_{2} \mathrm{O}_{2}$ concentrations for pilot-scale system

\begin{tabular}{|c|c|c|c|c|c|c|c|c|}
\hline & & \multicolumn{2}{|c|}{ Influent Conc. mg/L) } & \multicolumn{2}{|c|}{ Effluent Conc. (mg/L) } & \multicolumn{3}{|c|}{ Effluent } \\
\hline & Date/Time & PAA & $\mathrm{H}_{2} \mathrm{O}_{2}$ & PAA & $\mathrm{H}_{2} \mathrm{O}_{2}$ & $\mathrm{pH}$ & $\begin{array}{l}\text { Temp } \\
\left.{ }^{\circ} \mathrm{C}\right)\end{array}$ & E. coli \\
\hline \multirow{12}{*}{ 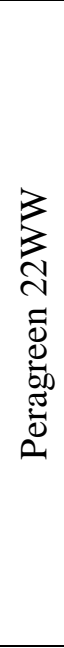 } & $12 / 19 / 1610: 45$ & 1.26 & 0.06 & 1.19 & 0.08 & 7.1 & 14.2 & 0 \\
\hline & 12/20/16 10:30 & 0.40 & 0.07 & 0.30 & 0.14 & 7.2 & 13.9 & 0 \\
\hline & $12 / 21 / 168: 20$ & 0.73 & 0.01 & 0.50 & 0.15 & 7.3 & 13.1 & 0 \\
\hline & 12/22/16 8:00 & 0.58 & 0.12 & 0.43 & 0.36 & 7.2 & 13.8 & 0 \\
\hline & 12/27/16 10:00 & 0.43 & 0.04 & 0.29 & 0.11 & 7.2 & 16.9 & 0 \\
\hline & 12/28/16 8:00 & 0.32 & 0.10 & 0.22 & 0.06 & 7.1 & 14.9 & TNTC \\
\hline & 12/29/16 8:15 & 0.33 & 0.03 & 0.16 & 0.12 & 7.1 & 15.8 & 0 \\
\hline & 1/3/17 8:00 & 0.33 & 0.06 & 0.20 & 0.15 & 7.3 & 15.7 & 10 \\
\hline & 1/4/17 8:00 & 0.40 & 0.01 & 0.26 & 0.10 & 7.1 & 15.8 & 3 \\
\hline & $1 / 5 / 177: 30$ & 0.37 & 0.04 & 0.30 & 0.06 & 7.1 & 13.9 & 3 \\
\hline & $1 / 6 / 178: 30$ & 0.32 & 0.02 & 0.24 & 0.12 & 7.0 & 13.6 & \\
\hline & 1/11/17 8:30 & 0.43 & 0.26 & 0.29 & 0.31 & 7.0 & 13.2 & 0 \\
\hline \multirow{18}{*}{ 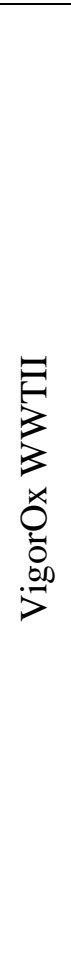 } & 1/12/17 8:00 & 0.50 & 0.05 & 0.28 & 0.17 & 7.0 & 14.5 & 0 \\
\hline & 1/13/17 8:00 & 0.44 & 0.09 & 0.34 & 0.33 & 7.0 & 15.5 & \\
\hline & 1/17/17 9:30 & 0.36 & 0.03 & 0.14 & 0.33 & 7.2 & 16.1 & 0 \\
\hline & 1/18/17 9:30 & 0.26 & 0.00 & 0.24 & 0.25 & 7.2 & 15.9 & 53 \\
\hline & 1/19/17 9:00 & 0.55 & 0.06 & 0.24 & 0.06 & 7.1 & 15.8 & TNTC \\
\hline & 1/20/17 9:00 & 0.80 & 0.05 & 0.26 & 0.06 & 7.1 & 16.3 & \\
\hline & 1/23/17 11:00 & 0.34 & 0.18 & 0.04 & 0.40 & 7.1 & 16.6 & 7 \\
\hline & 1/25/17 10:00 & 0.36 & 0.12 & 0.24 & 0.24 & 7.0 & 14.9 & \\
\hline & 1/26/17 8:30 & 0.45 & 0.17 & 0.22 & 0.18 & 7.1 & 15.9 & TNTC \\
\hline & $1 / 27 / 178: 20$ & 0.26 & 0.23 & 0.19 & 0.10 & 7.2 & 14.6 & 0 \\
\hline & 1/30/17 8:00 & 0.49 & 0.32 & 0.18 & 0.31 & 7.2 & 12.4 & 33 \\
\hline & $1 / 31 / 178: 15$ & 0.49 & 0.10 & 0.29 & 0.19 & 7.2 & 13.0 & 0 \\
\hline & $2 / 1 / 17$ 12:45 & 0.45 & 0.11 & 0.20 & 0.29 & 7.2 & 15.1 & 82 \\
\hline & $2 / 2 / 178: 30$ & 0.26 & 0.24 & 0.21 & 0.30 & 7.6 & 15.9 & 11 \\
\hline & $2 / 3 / 178: 20$ & 0.64 & 0.05 & 0.25 & 0.24 & 7.4 & 15.2 & \\
\hline & 2/7/17 8:00 & 0.76 & 0.06 & 0.28 & 0.16 & 7.3 & 15.3 & 0 \\
\hline & 2/8/17 8:15 & 0.19 & 0.14 & 0.17 & 0.15 & 7.3 & 25.0 & \\
\hline & 2/9/17 8:00 & 0.74 & 0.06 & 0.42 & 0.05 & 7.3 & 25.0 & 0 \\
\hline
\end{tabular}


The drop in PAA concentration through the pilot-scale contact chamber (PAA decay) averaged $0.19 \mathrm{mg} / \mathrm{L}$ (39\% reduction), with a maximum change of $0.54 \mathrm{mg} / \mathrm{L}(88 \%)$ and a minimum of $0.02 \mathrm{mg} / \mathrm{L}(5.6 \%)$. The wide variation in the PAA decay is probably a result of varying bacteria and dissolved organic concentrations in the influent stream to the contact chamber. The measured cBOD concentrations in the influent were always $<4 \mathrm{mg} / \mathrm{L}$; however, variation in the concentrations that were below the detection limit would be enough to impact the very low concentrations of PAA entering the contact chamber.

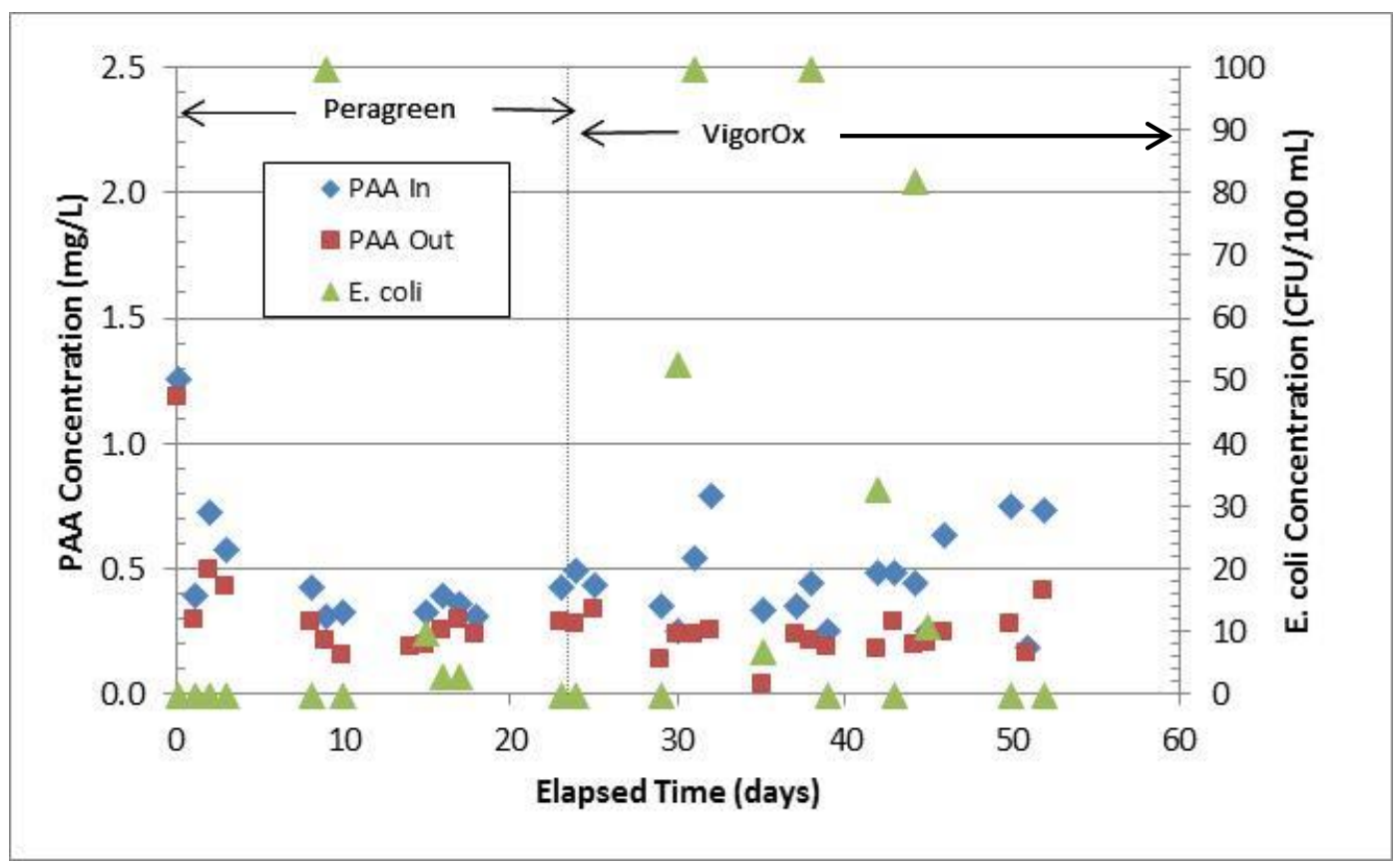

Fig. 3. PAA and E. coli concentrations for pilot-scale system

The cBOD concentration in the effluent was measured each week, and was less than the detection limit of $4 \mathrm{mg} / \mathrm{L}$ for all of the samples. The cBOD is routinely measured in the STP effluent, and all of these samples were also $<4 \mathrm{mg} / \mathrm{L}$ while the pilot-scale system was in operation, so the acetic acid in the PAA solution did not measurably increase the $\mathrm{cBOD}$. Based on the low PAA concentration that is needed for disinfection, the amount of acetic acid from the PAA solution that would be added to the STP effluent is expected to be $<1 \mathrm{mg} / \mathrm{L}$.

One effluent sample, taken on $1 / 5 / 17$, was tested for toxicity to Ceriodaphnia dubia, at the ORNL Toxicology Laboratory. The 48-hour toxicity test was started within one hour of taking the sample. The sample contained $0.30 \mathrm{mg} / \mathrm{L} \mathrm{PAA}$ and $0.06 \mathrm{mg} / \mathrm{L} \mathrm{H}_{2} \mathrm{O}_{2}$ when it was taken. Water quality parameters for the samples, measured at the Toxicology Laboratory, are shown in Table 2. The sample was tested for toxicity at $100 \%$ and $80 \%$ concentration, along with a control sample that contained $25 \%$ degassed mineral water in deionized water. The control water was also used to dilute the $80 \%$ effluent sample. Survival was $100 \%$ in all of the tests, from a total of 24 animals per test sample, so there was no measurable toxicity for the effluent. Samples of the effluent from the ORNL STP are also measured routinely at the Toxicology Laboratory, and they normally show no acute toxicity at $100 \%$ concentration. 
Table 2. Water quality parameters

\begin{tabular}{|c|c|}
\hline Parameter & Concentration \\
\hline Conductivity $(\mu \mathrm{S} / \mathrm{cm})$ & 608 \\
\hline Alkalinity $\left(\mathrm{mg} / \mathrm{L}\right.$ as $\left.\mathrm{CaCO}_{3}\right)$ & 89 \\
\hline Hardness $\left(\mathrm{mg} / \mathrm{L}\right.$ as $\left.\mathrm{CaCO}_{3}\right)$ & 166 \\
\hline
\end{tabular}

A graph of the E. coli vs. PAA concentrations in the effluent samples is shown in Figure 4. For effluent PAA concentrations below $0.25 \mathrm{mg} / \mathrm{L}$, there is a risk of relatively high $E$. coli concentrations, although the $E$. coli concentration was usually low even at lower PAA concentrations. There were 12 times that the effluent PAA concentration was $<0.25 \mathrm{mg} / \mathrm{L}$ when $E$. coli concentrations were measured, and four of those times the E. coli concentration was above $80 \mathrm{CFU} / 100 \mathrm{~mL}$. The high E. coli concentrations usually occurred after heavy rain, when the organic concentration in the STP effluent is likely to be higher, or after a flow disruption in the pilot-scale system. In order to provide more of a safety factor for disinfection in the STP effluent, it is recommended that the effluent concentration be kept above $0.3 \mathrm{mg} / \mathrm{L}$ PAA. Based on a fairly small number of measurements at higher PAA concentrations, the influent concentration would need to be above $0.6 \mathrm{mg} / \mathrm{L}$ PAA to ensure that the effluent remains above $0.3 \mathrm{mg} / \mathrm{L}$, which should result in consistently low E. coli concentrations.

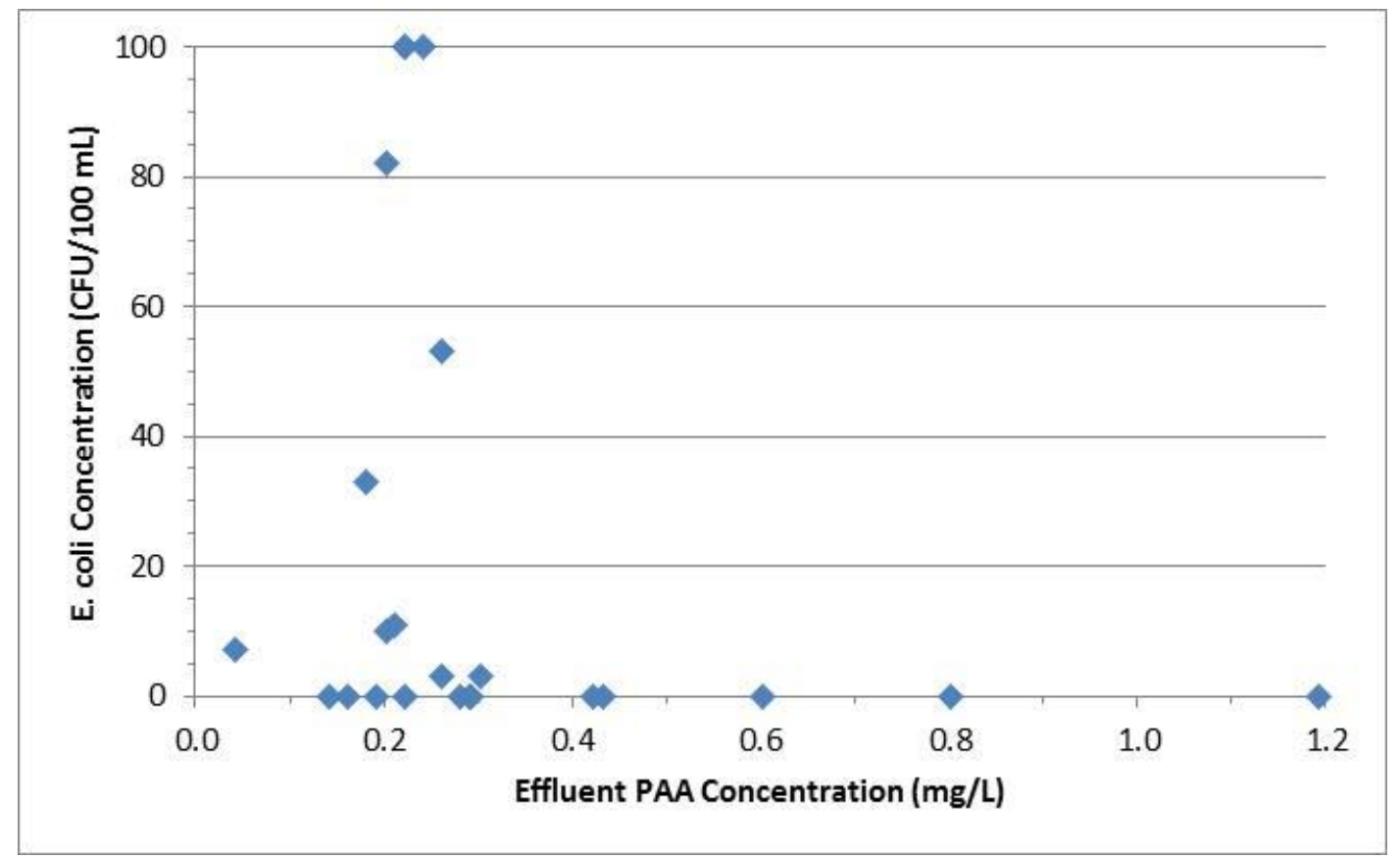

Fig. 4. PAA vs. E. coli concentrations for pilot-scale system effluent 


\section{Full-Scale Implementation Plan}

Based on the results of the pilot-scale test, a dosage of at least $0.6 \mathrm{mg} / \mathrm{L}$ PAA in the STP effluent would provide adequate disinfection of the effluent while at the same time preventing toxic conditions in the receiving stream from PAA (i.e., no neutralization of the PAA and $\mathrm{H}_{2} \mathrm{O}_{2}$ would be required). It is recommended that DOE submit an Engineering Report that would describe the permanent installation/operation of a PAA disinfecting unit to the Tennessee Department of Environment and Conservation, and request an NPDES permit modification to allow implementation of PAA disinfection with a compliance schedule that would include instream bioassessment upstream and downstream (near

field and far field) of the effluent discharge point (Outfall X01). The existing ozone generators would be kept as a backup system. 